\title{
Electroanalytical Procedure for the Determination of Methylparathion in Soil Suspensions and its Application for Sorption Studies with Brazilian Soils
}

\author{
Giuliane M. Castanho ${ }^{*, a, b}$ Carlos M. P. Vaz ${ }^{a}$ and Sérgio A. S. Machado ${ }^{b}$ \\ ${ }^{a}$ Embrapa Instrumentação Agropecuária, CP 741, 13560-970 São Carlos - SP, Brasil \\ ${ }^{b}$ Instituto de Química de São Carlos, Universidade de São Paulo, CP 780, 13560-970 São Carlos - SP, Brazil
}

\begin{abstract}
A técnica de polarografia de pulso diferencial foi usada para estabelecer um procedimento eletroanalítico para a determinação do inseticida organofosforado parathion metílico (tiofosfato de dimetilparanitrofenila) em amostras de solo. Foram observados 3 picos de redução do metilparathion sobre eletrodo de mercúrio, em função do $\mathrm{pH}$ da solução. $\mathrm{O}$ pico mais catódico $(\mathrm{Ep}=-0,55 \mathrm{~V})$, observado apenas em pH's maiores que 5,0, foi selecionado para as determinações analíticas. O limite de detecção encontrado foi de $1,93 \times 10^{-8} \mathrm{~mol} \mathrm{~L}^{-1}$ para água pura e de cerca de $8 \times 10^{-8} \mathrm{~mol} \mathrm{~L}^{-1}$ para as amostras de solo, com velocidade de varredura de $2 \mathrm{mV} \mathrm{s}^{-1}$ e $\mathrm{pH}$ da solução de 6,75 . O procedimento eletroanalítico desenvolvido foi utilizado para a obtenção de isotermas de sorção do parathion metílico em 3 solos do Estado de São Paulo, com distintos teores de argila, matéria orgânica e pH. O modelo de isoterma de Freundlich apresentou um excelente ajuste aos dados experimentais e os coeficientes de Freundlich $\left(\mathrm{K}_{\mathrm{F}}\right)$ obtidos para cada solo apresentaram valores entre 7 e $29 \mathrm{~L} \mathrm{~kg}^{-1}$, sendo considerados como de baixa a média capacidade de sorção nos solos estudados, de acordo com o critério do IBAMA (Instituto Brasileiro de Meio Ambiente e dos Recursos Renováveis). Os teores de matéria orgânica e argila dos solos foram os fatores que mais influenciaram a sorção do metilparathion nesses solos.
\end{abstract}

The differential pulse polarography technique was used to establish an electroanalytical procedure for the determination of the organophosphorous insecticide methyl parathion (O,O-dimethyl O-(4nitrophenyl) phosphorothioate) in soil samples. Three reduction peaks were observed in mercury electrodes as a function of the solution $\mathrm{pH}$. The more cathodic peak $\left(\mathrm{E}_{\mathrm{p}}=-0.55 \mathrm{~V}\right)$, only observed for $\mathrm{pH}$ values higher than 5.0, was chosen for the analytical determinations. The limit of detection was $1.93 \times 10^{-8} \mathrm{~mol} \mathrm{~L}^{-1}$ for pure water and about $8 \times 10^{-8} \mathrm{~mol} \mathrm{~L}^{-1}$ for soil suspensions with a scan rate of 2 $\mathrm{mV} \mathrm{s}^{-1}$ and a $\mathrm{pH}$ of 6.75 . The electroanalytical procedure developed was applied for the determination of sorption isotherms of methylparathion on 3 soils from São Paulo State, Brazil, at different $\mathrm{pH}$ and diverse amounts of clay and organic matter. The experimental data were fitted using the Freundlich isotherm model and the Freundlich coefficients $\left(\mathrm{K}_{\mathrm{F}}\right)$ obtained for each soil varied from 7 to $29 \mathrm{~L} \mathrm{~kg}^{-1}$, representing a low to medium sorption capacity, according to the IBAMA (Brazilian Environmental Protection Agency) standards. The amounts of organic matter and clay were the most important soil parameters controling the sorption of methylparathion by these soils.

Keywords: methylparathion, pesticide, polarography, soils, sorption isotherms

\section{Introduction}

Pesticides have been used in the agriculture production to increase yields, improve food quality and save time and money. However, as toxic substances, several environmental and health problems occurred associated with their use. In order to reduce the environmental impact, poisoning and other problems, it is very important to know

\footnotetext{
* e-mail: giuliane@cnpdia.embrapa.br
}

the interaction mechanisms and the fate of these substances in the environment where they are applied.

Organophosphorous compounds are the most important insecticides used in the Brazilian agriculture for pest control. Their uninformed use can cause soil, water and food contamination. ${ }^{1}$ Methylparathion (Figure 1) is an organophosphorous insecticide very effective against many pests in important crops such as bulbs, cereals, fruits, vegetables, cotton, peanuts, soybean, potato, sugar cane, coffee, alfalfa and pasture. It acts by contact, ingestion and inhalation, ${ }^{2}$ and is a well-known inhibitor of 
<smiles>COP(=S)(OC)Oc1ccc([N+](=O)[O-])cc1</smiles>

Figure 1. Chemical structure of methylparathion.

acetylcolinesterase (essential for the operation of the central nervous system of the insects), therefore, producing serious damage and death. ${ }^{3}$ It is classified in toxicological class 1, meaning that it is extremely dangerous for mammals.

The most used analytical procedures for the determination of pesticide compounds are the chromatographic ones, but electroanalytical techniques have also been used for the determination and study of several pesticides in different matrixes like natural water, soils, plants and food. ${ }^{4}$ Despite its lower selectivity and sensitivity, in some cases, when compared to chromatography, the electroanalytical procedures have several advantages such as their low cost and the possibility of analysis without the need of extraction or pre-treatments, as well as the short time required for the analysis. ${ }^{5-7}$

Some features of the electrochemical behavior of the organophosphorous insecticide methylparathion over mercury electrodes have been already studied, ${ }^{8-12}$ but there is no complete electroanalytical method established for its determination in natural samples, using this electrode.

As this compound is an aromatic nitro derivate, its analysis is possible using polarography and voltammetry, due the fact that the nitrobenzene group is easily reduced at the mercury electrode..$^{13}$

Sorption coefficients of pesticides are important parameters because they play an important role on the fate of pesticides in the environment and therefore they are relevant to assess the risk of ground or surface water contamination by pesticides. Besides this, there are few data in the literature about sorption of pesticides in Brazilian soils, limiting the application of models for the prediction of pesticides contamination. ${ }^{14}$ For these reasons we have developed an electroanalytical procedure, using differential pulse voltammetry (DPV) and polarography (DPP) and square wave voltammetry (SWV), for determining methylparathion in soil suspension and for the determination of its sorption coefficients in 3 Brazilian soils.

\section{Experimental}

\section{Materials}

Methylparathion (O,O-dimethyl O-(4-nitrophenyl) phosphorothioate) was supplied by Bayer (Brazil) with a purity of $80.66 \%$. A stock solution of $7.6 \times 10^{-3} \mathrm{~mol} \mathrm{~L}^{-1}$ (2000 $\mu \mathrm{g} \mathrm{mL}^{-1}$ ) was prepared in ethanol and used in all experiments. Samples with lower concentrations were obtained from the original stock solution by dilution with aqueous $0.01 \mathrm{~mol} \mathrm{~L}^{-1}$ calcium chloride $\left(\mathrm{CaCl}_{2}\right)$, chosen as the support eletrolyte.

Soils used in this study were collected in the city of São Carlos, in São Paulo state, Brazil, consisting of a very sandy soil (Areia Quartzosa - AQ), a very clayed soil (Latossolo Roxo - LR) and a medium clayed soil (Latossolo Vermelho Amarelo - LVA), being representative of the soils occurring in São Paulo State. Some properties of these soils are presented in Table 1.

\section{Instrumentation}

The electrochemical analyses were carried out in an electrochemical trace analyzer, model 394, from EG\&G Parc with a hanging mercury drop electrode (voltammetry) and dropping mercury electrode (polarography), model 303A from EG\&G Parc. The reference electrode was Ag/ $\mathrm{AgCl}$ and the counter electrode was a platinum wire. The $\mathrm{pH}$ of the solutions was measured using a pHmeter from Analion, model PM606F.

\section{Electroanalytical measurements}

Differential pulse voltammograms and polarograms and square wave voltammograms were obtained with medium size mercury drop, scan rate of $2 \mathrm{mV} \mathrm{s}^{-1}$, pulse height of $50 \mathrm{mV}$ and a nitrogen purging time of $10 \mathrm{~min}$. The scan rate frequency for the square wave voltammetry technique was $60 \mathrm{~Hz}$. All voltammograms and polarograms were obtained in triplicate for each sample.

In order to study the electrochemical behavior of methylparathion as a function of $\mathrm{pH}$, experiments were carried out with methylparathion concentration of $1.1 \mathrm{x}$

Table 1. Characteristics of the soils studied

\begin{tabular}{lccccccc}
\hline Soil & $\begin{array}{c}\text { Occurrence in São Paulo } \\
\text { state }(\% \text { of total area) }\end{array}$ & Texture Class & $\begin{array}{c}\text { Organic Matter } \\
(\%)\end{array}$ & $\begin{array}{c}\mathrm{pH} \text { in } \\
\mathrm{CaCl}_{2}\end{array}$ & $\begin{array}{c}\text { Clay } \\
(\%)\end{array}$ & $\begin{array}{c}\text { Silt } \\
(\%)\end{array}$ & $\begin{array}{c}\text { Sand } \\
(\%)\end{array}$ \\
\hline LVA & 13 & Medium clayed & 3.1 & 4.3 & 32 & 6 & 62 \\
LR & 14 & Clayed & 5.4 & 4.7 & 49 & 8 & 43 \\
AQ & 5 & Sandy & 1.1 & 4.6 & 8 & 6 & 86 \\
\hline
\end{tabular}


$10^{-4} \mathrm{~mol} \mathrm{~L}^{-1}\left(30 \mu \mathrm{g} \mathrm{mL}^{-1}\right)$ in $0.01 \mathrm{~mol} \mathrm{~L}^{-1} \mathrm{CaCl}_{2}$ in the $\mathrm{pH}$ range varying from 2 to 11 , adjusted with $\mathrm{HCl}$ or $\mathrm{NaOH}$. The optimum $\mathrm{pH}$ was determined considering the maximum current and adequate potential peak.

An analytical curve of methylparathion in $0.01 \mathrm{~mol} \mathrm{~L}^{-1}$ $\mathrm{CaCl}_{2}$ was obtained at $\mathrm{pH} 6.75$, the previously established optimum $\mathrm{pH}$, by standard addition of methylparathion with concentrations ranging from $3.8 \times 10^{-6}$ to $1.1 \times 10^{-4} \mathrm{~mol} \mathrm{~L}^{-1}$ (1.0 to $30 \mu \mathrm{g} \mathrm{mL}^{-1}$ ), using the three techniques (DPP, DPV and SWV). The limit of detection (LD) for each technique was determined as $\mathrm{LD}=3 \sigma / \operatorname{tg} \alpha$, where $\sigma(\mathrm{nA})$ is the current standard deviation of 10 voltammograms of blank samples and $\operatorname{tg} \alpha\left(\mathrm{nA} / \mu \mathrm{g} \mathrm{L}^{-1}\right)$ is the slope of the analytical curve.

\section{Adsorption isotherms}

Sorption isotherms were determined in batch experiments using 9 samples of each soil, containing $2 \mathrm{~g}$ of soil and $20 \mathrm{~mL}$ of a solution with methylparathion in $0.01 \mathrm{~mol} \mathrm{~L}^{-1}$ $\mathrm{CaCl}_{2}$ in the following concentrations: 0 (blank), 0.1, 0.25, $0.5,1,2.5,5,10$ and $20 \mu \mathrm{g} \mathrm{mL}^{-1}$, according to the procedure suggested by IBAMA. ${ }^{15}$ Samples were placed in $50 \mathrm{~mL}$ centrifuge tubes, shaken for $24 \mathrm{~h}$ and centrifuged for 20 minutes at $15000 \mathrm{rpm}$. From the supernatant, $10 \mathrm{~mL}$ aliquots were collected, transferred to the polarographic cell, adjusted to $\mathrm{pH} 6.75$ and analyzed by DPP. Analytical curves were obtained for each soil by standard addition of methylparathion in the blank samples, ranging from 0.1 to $20 \mu \mathrm{g} \mathrm{mL}^{-1}\left(3.8 \times 10^{-7}\right.$ to $\left.7.6 \times 10^{-5} \mathrm{~mol} \mathrm{~L}^{-1}\right)$, allowing the determination of its equilibrium concentration, also measured by DPP.

Freundlich sorption isotherm (equation 1) has been used for fitting the pesticides sorption data ${ }^{16,17}$

$\mathrm{X} / \mathrm{M}=\mathrm{K}_{\mathrm{F}} \mathrm{Ce}^{1 / \mathrm{n}}$

where $\mathrm{X} / \mathrm{M}\left(\mu \mathrm{g} \mathrm{g}^{-1}\right)$ is the amount of pesticide sorbed by unit of soil mass, $\mathrm{K}_{\mathrm{F}}\left(\mathrm{L} \mathrm{kg}^{-1}\right)$ is the Freundlich sorption coefficient, $1 / \mathrm{n}$ is a parameter that depends on the sorbed substance and the substrate, and $\mathrm{Ce}\left(\mu \mathrm{g} \mathrm{L}^{-1}\right)$ is the pesticide equilibrium concentration.

For the cases where $1 / \mathrm{n}$ approaches 1 , the Freundlich equation becomes:

$\mathrm{X} / \mathrm{M}=\mathrm{K}_{\mathrm{d}} \mathrm{Ce}$

where the distribution coefficient, $\mathrm{K}_{\mathrm{d}},\left(\mathrm{L} \mathrm{kg}^{-1}\right)$ is assumed to equal $\mathrm{K}_{\mathrm{F}}$. Although equation (2) is valid only when $1 / \mathrm{n}=1$, it has been used as a practical index for most of the pesticides sorption studies conducted in batch experiments. ${ }^{17}$
The sorption isotherm parameters, Freundlich $\left(\mathrm{K}_{\mathrm{F}}\right)$ and the distribution coefficient $\left(\mathrm{K}_{\mathrm{d}}\right){ }^{15,16}$ were determined through log-log and linear plots, of the amount sorbed per mass of soil (X/M; $\left.\mu \mathrm{g} \mathrm{g}^{-1}\right)$ versus the equilibrium concentration of the solution $\left(\mathrm{Ce} ; \mu \mathrm{g} \mathrm{mL}^{-1}\right)$. The amount of methylparathion sorbed in the soil was calculated as the difference between the added and the equilibrium concentrations.

\section{Results and Discussion}

\section{Electroanalytical procedure}

The voltammetric and polarographic responses of methylparathion as a function of $\mathrm{pH}$ showed two different reduction processes (Figure 2): one, $\mathrm{pH}$ dependent, (peak 1 and 3 ) at the low $\mathrm{pH}$ range ( $\mathrm{pH} 1$ to 5) and another, $\mathrm{pH}$ independent, (peak potential $=-0.55 \mathrm{~V}$ ) for $\mathrm{pH}$ values higher than 5.0 (peak 2). Figures 3 and 4 show the peak current and potential for the three peaks as a function of the $\mathrm{pH}$. Therefore, when in the lower $\mathrm{pH}$ range ( $\mathrm{pH} 1$ to 5), two peaks are observed (peak 1 and 3), whose peak currents decrease and whose potentials increase in the cathodic direction as the $\mathrm{pH}$ increases. Peaks 1 and 3 disappear at $\mathrm{pH}$ values higher than 5 and another peak can be observed at the potential of $-0.55 \mathrm{~V}$ (peak 2) displaying potential and current practically independent of the $\mathrm{pH}$.

According to the literature, methylparathion exhibits one or two electrochemical reduction processes, depending

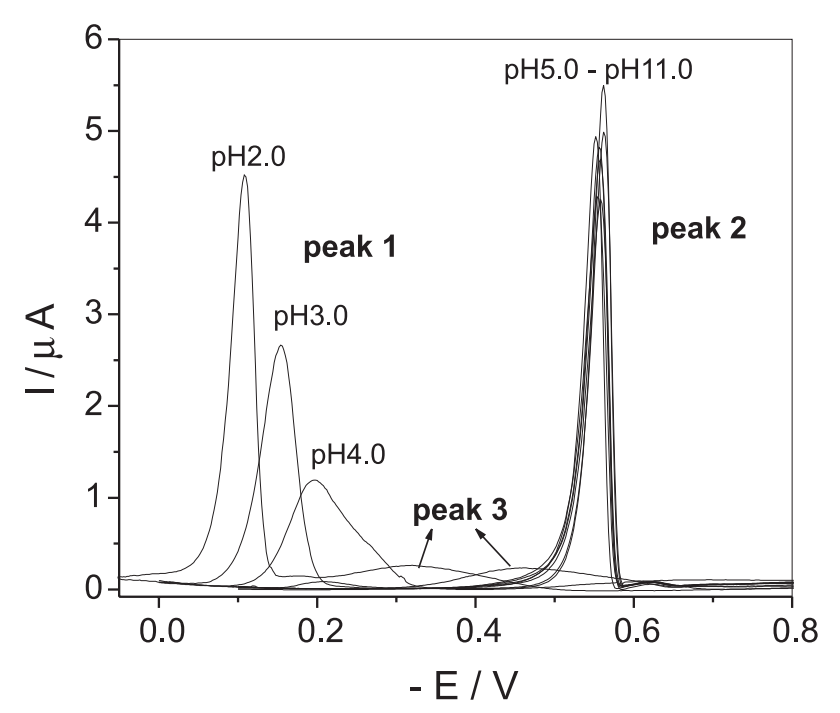

Figure 2. Differential pulse polarograms of $1.1 \times 10^{-4} \mathrm{~mol} \mathrm{~L}^{-1}$ methylparathion in $0.01 \mathrm{~mol} \mathrm{~L}^{-1} \mathrm{CaCl}_{2}$, as a function of the $\mathrm{pH}$ (adjusted with $\mathrm{HCl}$ or $\mathrm{NaOH}$ ), using $\mathrm{HMDE}$ as working electrode, $\mathrm{Ag} / \mathrm{AgCl}$ as reference electrode, $\mathrm{Pt}$ as auxiliary electrode and a scan rate of $2 \mathrm{mVs}^{-1}$. 
on the $\mathrm{pH}$ of the medium..$^{10-12}$ In very acidic medium $(\mathrm{pH}<1.8)$ only one peak was detected and six electrons were exchanged in the redox reduction of the nitroaromatic group. ${ }^{10}$ In our study the electrochemical behavior of methylparathion was studied only at $\mathrm{pH}$ above 2.0. For $1.8<\mathrm{pH}<5$, two peaks were observed, one very well-defined and other ill-defined, ${ }^{10}$ named peaks 1 and 3, respectively, in the present work. As suggested in the literature, ${ }^{10-12}$ four and two electrons were involved in those redox process, respectively for peaks 1 and 3 . In neutral and alkaline media, a process involving four electrons was observed in the reduction of this pesticide ${ }^{10-12}$ (named peak 2 in the

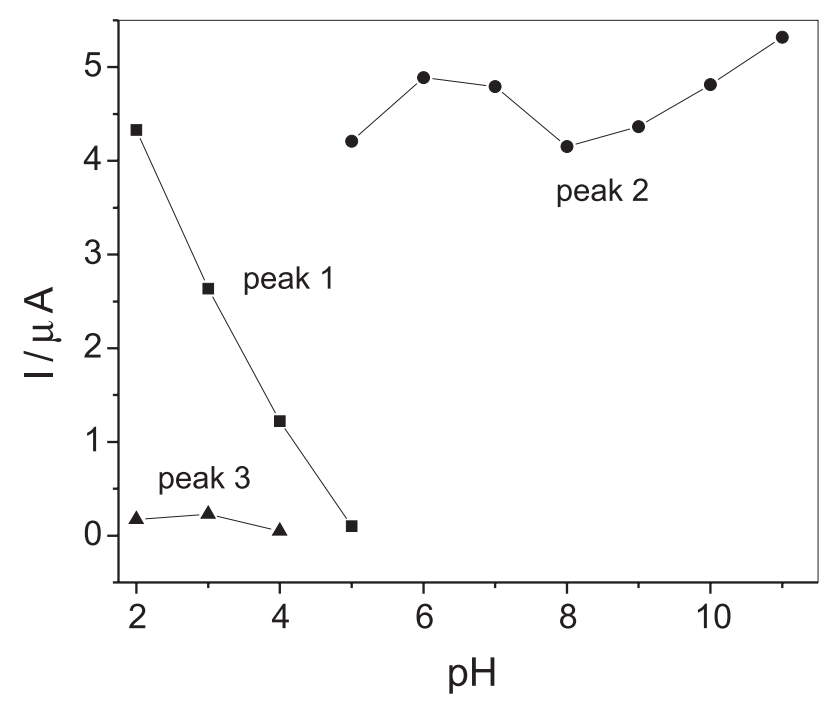

Figure 3. Variation of the peak current as a function of the $\mathrm{pH}$, obtained from polarograms presented in Figure 2.

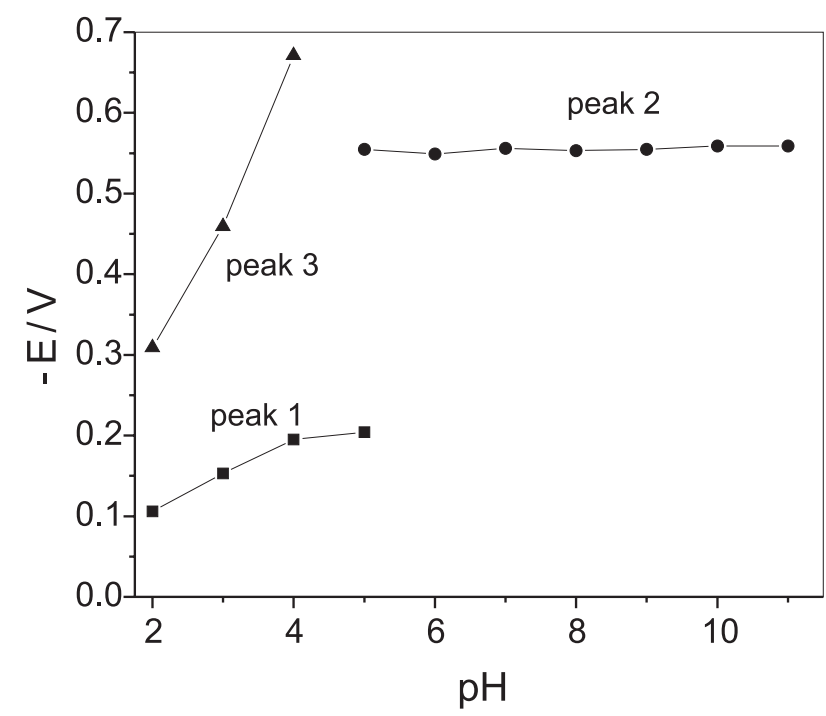

Figure 4. Variation of the peak potential as a function of the $\mathrm{pH}$, obtained from polarograms presented in Figure 2. present work). For $\mathrm{pH}>8$, hydrolysis of methylparation takes place, which affects the current intensity values, turning them time and $\mathrm{pH}$ dependent. ${ }^{10}$ For this reason, in our study, samples were $\mathrm{pH}$ adjusted and immediately analyzed, minimizing the hydrolysis reaction at the studied $\mathrm{pH}$ range.

Peak 2 (more cathodic) was chosen for the analytical application because of its higher peak current, its independence on $\mathrm{pH}$ and the favorable $\mathrm{pH}$ range, since most natural waters (including this soil suspension) present $\mathrm{pH}$ close to neutral and, therefore, the $\mathrm{pH}$ sample adjustment is facilitated or unnecessary. The $\mathrm{pH}$ of 6.75 was chosen for further studies, since this was the $\mathrm{pH}$ obtained for a solution of $1.1 \times 10^{-4} \mathrm{~mol} \mathrm{~L}^{-1}$ methylparathion in $0.01 \mathrm{~mol} \mathrm{~L}^{-1} \mathrm{CaCl}_{2}$.

Differential pulse polarograms (DPP) obtained by standard addition of methylparathion in $0.01 \mathrm{~mol} \mathrm{~L}^{-1} \mathrm{CaCl}_{2}$ and $\mathrm{pH} 6.75$ are presented in Figure 5 and the analytical curves obtained for the three techniques are shown in Figure 6 , for concentrations between $3.8 \times 10^{-6}$ and $1.1 \times 10^{-4} \mathrm{~mol} \mathrm{~L}^{-1}$ (1.0 to $30 \mu \mathrm{g} \mathrm{mL}^{-1}$ ).

Limits for the detection of methylparathion with the three techniques are shown in Table 2. The lowest limit of detection was obtained with the DPP technique $(1.93 \mathrm{x}$ $\left.10^{-8} \mathrm{~mol} \mathrm{~L}^{-1}\right)$. Although the peak current values and, therefore, $\operatorname{tg} \alpha$ are greater for SWV, the blank repetition values (blank standard deviation, $\sigma$ ) have shown much higher variation, leading to a greater limit of detection, as presented in Table 2. Therefore, DPP was chosen for measuring the methylparathion concentrations in the soil suspension samples during the sorption isotherms experiments.

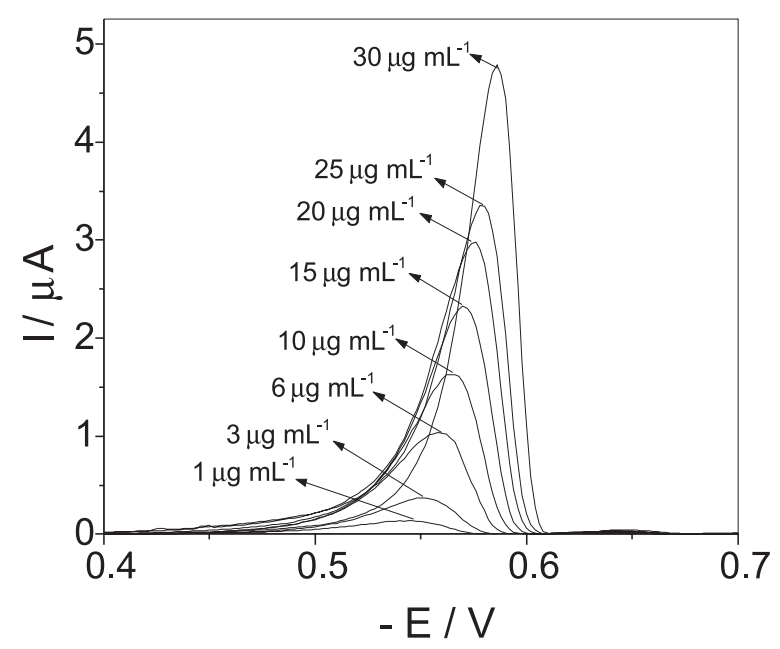

Figure 5. Differential pulse polarograms (subtracted from blank) for methylparathion for concentrations ranging from $3.8 \times 10^{-6} \mathrm{~mol} \mathrm{~L}^{-1}$ $\left(1.0 \mu \mathrm{g} \mathrm{mL}^{-1}\right)$ to $1.1 \times 10^{-4} \mathrm{~mol} \mathrm{~L}^{-1}\left(30 \mu \mathrm{g} \mathrm{mL}^{-1}\right)$, in $0.01 \mathrm{~mol} \mathrm{~L}^{-1} \mathrm{CaCl}_{2}$. Reference electrode: $\mathrm{Ag} / \mathrm{AgCl}$; scan rate: $2 \mathrm{mV} \mathrm{s}^{-1}$. 


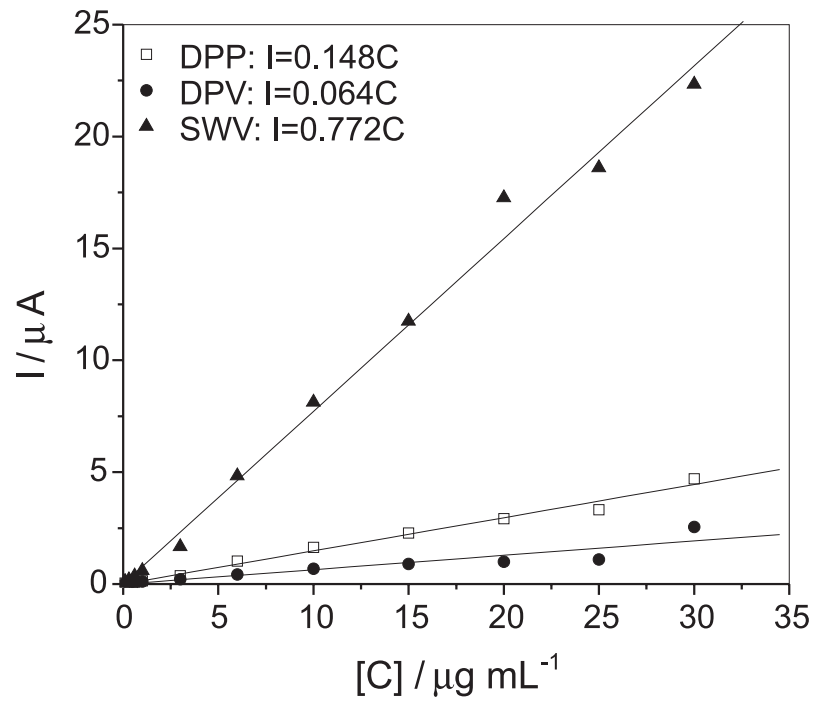

Figure 6. Calibration curves obtained from standard additions of methylparathion in $0.01 \mathrm{~mol} \mathrm{~L}^{-1} \mathrm{CaCl}_{2}$ for the DPP, DPV and SWV techniques.

\section{Sorption studies in different soils}

Figure 7 shows polarograms of methylparathion for the Areia Quartzosa soil, obtained by standard addition. Limits of detection for the soil solution samples (around $8 \times 10^{-8} \mathrm{~mol} \mathrm{~L}^{-1}$ ) were higher than the ones obtained in pure water, as can be seen in Figure 8 and Table 3 using the DPP technique, probably due to the presence of contaminants in the soil solution.

A closer look at the analytical curves of Figure 8 reveals that they do not display a linear behavior. Therefore, assuming linear calibration curves in this case can cause significant imprecision in the sample concentrations, mainly in the low concentration range. To overcome this problem, we have used a power function $\left(\mathrm{I}_{\mathrm{p}}=\mathrm{aC}^{\mathrm{b}}\right.$, where a and $\mathrm{b}$ are fitting parameters) to represent the experimental calibration data in the concentration range used $\left(3.8 \times 10^{-7}\right.$ to $\left.1.1 \times 10^{-4} \mathrm{~mol} \mathrm{~L}^{-1}\right)$. Figure 9 shows the fitted power curves and the fitted parameters $\mathrm{a}$ and $\mathrm{b}$ for the three soil samples.

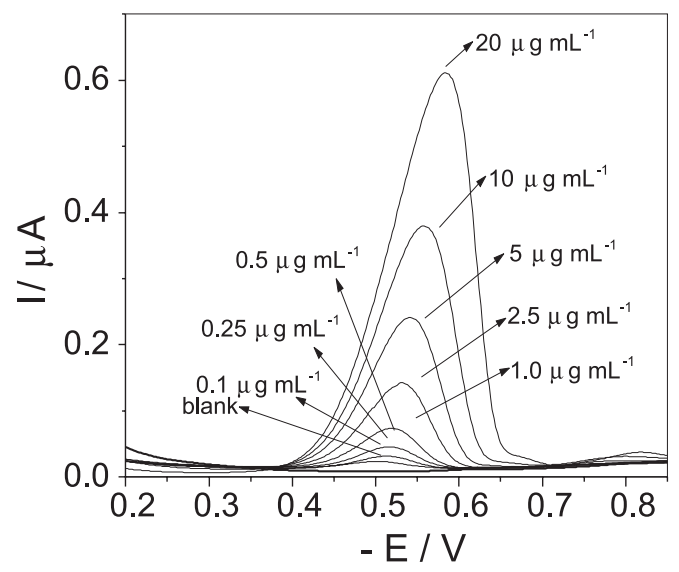

Figure 7. Differential pulse polarograms of methylparation in the Areia Quartzosa soil solution using $\mathrm{CaCl}_{2}$ as supporting electrode, for concentrations ranging from $3.8 \times 10^{-7} \mathrm{~mol} \mathrm{~L}^{-1}\left(0.1 \mu \mathrm{g} \mathrm{mL} \mathrm{g}^{-1}\right)$ to $7.8 \times 10^{-5} \mathrm{~mol} \mathrm{~L}^{-1}\left(20 \mu \mathrm{g} \mathrm{mL}^{-1}\right)$. Reference electrode: $\mathrm{Ag} / \mathrm{AgCl}$, scan rate: $2 \mathrm{mV} \mathrm{s}^{-1}$.

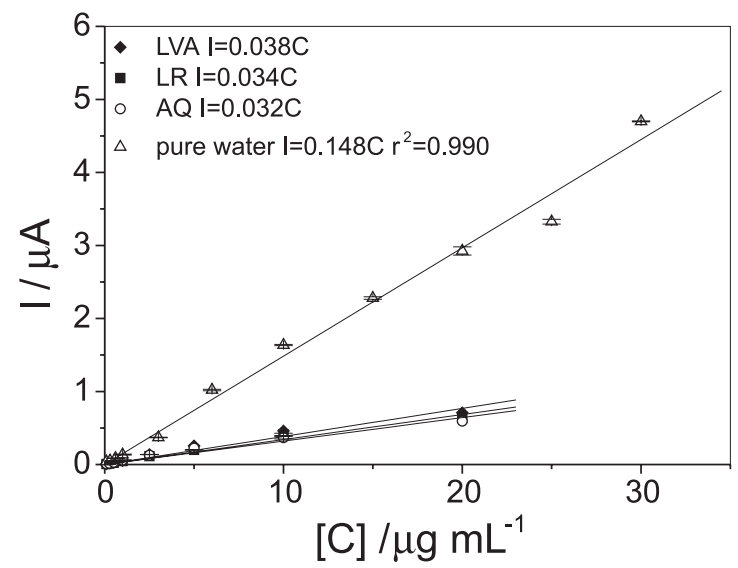

Figure 8. Linear calibration curves obtained from standard addition of methylparathion in the soil samples and pure water. Reference electrode: $\mathrm{Ag} / \mathrm{AgCl}$, scan rate: $2 \mathrm{mV} \mathrm{s}^{-1}$.

Table 2. Limits of detection (LD) for DPP, DPV and SWV techniques

\begin{tabular}{lccccr}
\hline Technique & Blank $\sigma$ & $\mathrm{r}^{2}$ & $\operatorname{tg} \alpha\left(\mu \mathrm{A} / \mu \mathrm{g} \mathrm{mL}^{-1}\right)$ & $\mathrm{LD}\left(\mathrm{mol} \mathrm{L}^{-1}\right)$ & $\left.\mathrm{LD}^{\prime}(\mu \mathrm{g} \mathrm{L})^{-1}\right)$ \\
\hline DPP & 0.251 & 0.99 & 0.148 & $1.93 \times 10^{-8}$ & 5.1 \\
DPV & 0.879 & 0.97 & 0.064 & $1.53 \times 10^{-7}$ & 40.2 \\
SWV & 37.79 & 0.99 & 0.772 & $5.58 \times 10^{-7}$ & 146.8 \\
\hline
\end{tabular}

$\sigma$ is the standard deviation of 10 measurements, $\operatorname{tg} \alpha$ is the angular coefficient of the standard addition ( $\mathrm{I}_{\mathrm{p}} \mathrm{vs} \mathrm{C}$ ) and $\mathrm{r}^{2}$ is the correlation coefficient.

Table 3. Limits of detection (LD) for the 3 soils studied, obtained using the DPP technique

\begin{tabular}{lccccc}
\hline Soil & Blank $\sigma$ & $\mathrm{r}^{2}$ & $\operatorname{tg} \alpha\left(\mu \mathrm{A} / \mu \mathrm{g} \mathrm{mL}^{-1}\right)$ & $\mathrm{LD}\left(\mathrm{mol} \mathrm{L}^{-1}\right)$ & $\left.\mathrm{LD}^{2}(\mu \mathrm{g} \mathrm{L})^{-1}\right)$ \\
\hline LVA & 0.2843 & 0.98 & 0.038 & $8.54 \times 10^{-8}$ & 22.4 \\
LR & 0.2487 & 0.98 & 0.034 & $8.33 \times 10^{-8}$ & 21.9 \\
AQ & 0.2382 & 0.98 & 0.032 & $8.48 \times 10^{-8}$ & 22.3 \\
\hline
\end{tabular}


Although there is still controversy about using power functions for the mathematical representation of these analytical curves, we have chosen this procedure because we found it more precise to estimate the pesticide concentrations, as can be verified in Table 4 by means of the correlation coefficients $r^{2}$ and root mean square errors (RMSE) for each soil sample. An increment of $r^{2}$ and a decrease in RMSE can be observed, ensuring a better representation of the analytical curves and, consequently, an improvement in the estimates of pesticide concentration.

The sorption isotherms were obtained using the equilibrium concentrations measured by DPP. The amount of sorbed methylparathion (X/M, $\mu \mathrm{g} \mathrm{g}^{-1}$ ) was calculated as the difference between the added and the measured

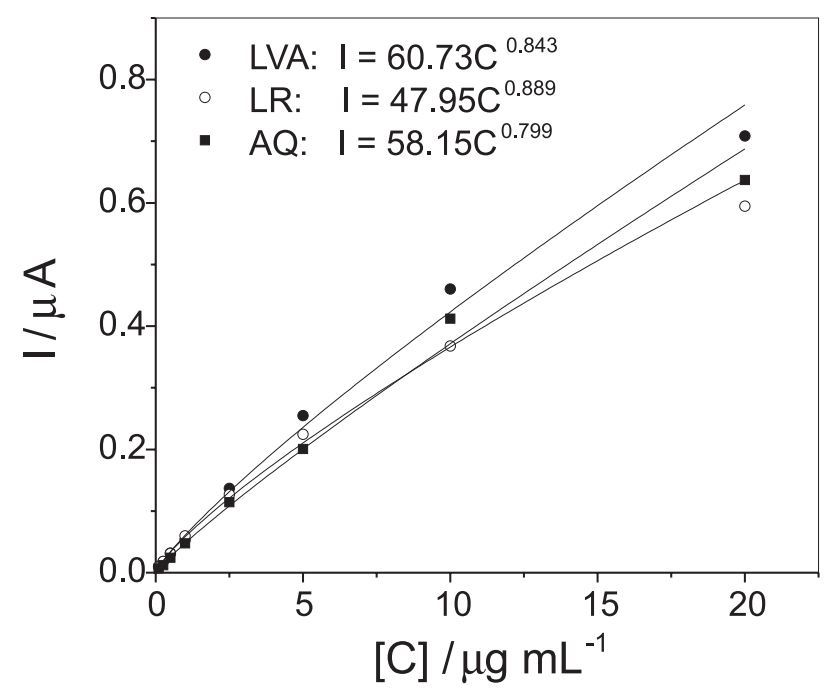

Figure 9. Calibration curves (power function) obtained from standard addition of methylparathion in the samples using the DPP technique.

Table 4. Correlation coefficient $\left(r^{2}\right)$ and root mean square error (RMSE) of the fitted linear and power functions from data for the standard addition of methylparation to the soil suspensions

\begin{tabular}{lcccc}
\hline Soil & \multicolumn{2}{c}{$\mathrm{r}^{2}$} & \multicolumn{2}{c}{ RMSE } \\
& linear & power & linear & power \\
\hline LVA & 0.98 & 0.99 & 27.8 & 15.8 \\
LR & 0.98 & 0.99 & 35.9 & 23.4 \\
AQ & 0.98 & 0.99 & 29.0 & 23.1 \\
\hline
\end{tabular}

concentration in solution. The isotherms, in the linear and $\log$-log forms are shown in Figures 10 and 11, respectively, allowing the determination of the distribution coefficient $\left(\mathrm{K}_{\mathrm{d}}\right)$ and the Freundlich sorption parameters $\left(\mathrm{K}_{\mathrm{F}}\right.$ and $\left.1 / \mathrm{n}\right)$ for each soil, which are presented in Table 5.

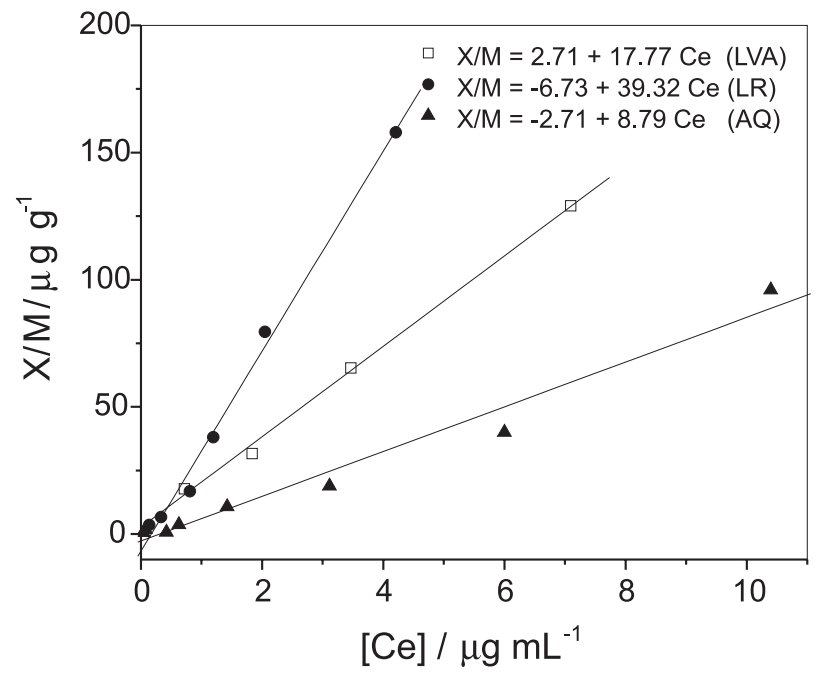

Figure 10. Sorption isotherms of methylparathion for the 3 soils studied. $\mathrm{X} / \mathrm{M}$ is the amount of the insecticide sorbed by unit of soil mean and $\mathrm{Ce}$ is the sample concentration after equilibrium.

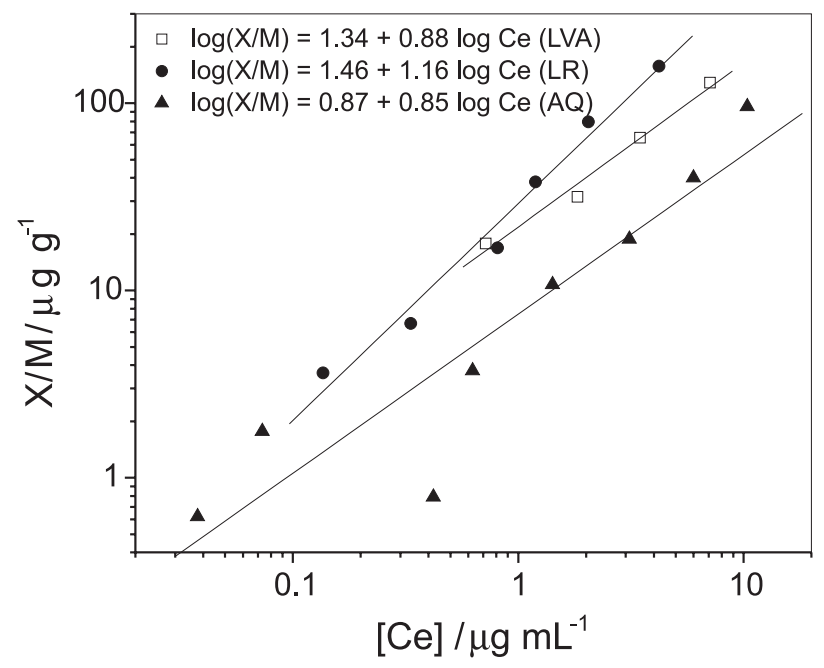

Figure 11. Freundlich sorption isotherms for the 3 soils studied.

Table 5. Sorption parameters for the 3 soils studied

\begin{tabular}{|c|c|c|c|c|c|}
\hline Soil & Linear isotherm $r^{2}$ & Freundlich isotherm $r^{2}$ & $\mathrm{~K}_{\mathrm{d}}\left(\mathrm{L} \mathrm{kg}^{-1}\right)$ & $\mathrm{K}_{\mathrm{f}}\left(\mathrm{L} \mathrm{kg}^{-1}\right)$ & $1 / \mathrm{n}$ \\
\hline LVA & 0.99 & 0.98 & 17.8 & 21.8 & 0.88 \\
\hline LR & 0.99 & 0.98 & 39.3 & 29.1 & 1.16 \\
\hline AQ & 0.97 & 0.86 & 8.8 & 7.5 & 0.85 \\
\hline
\end{tabular}

$\mathrm{K}_{\mathrm{d}}$ is the partition coefficient and $\mathrm{K}_{\mathrm{F}}$ and $1 / \mathrm{n}$ are the Freundlich sorption coefficients. 
An increment in the distribution $\left(\mathrm{K}_{\mathrm{d}}\right)$ and Freundlich $\left(\mathrm{K}_{\mathrm{F}}\right)$ coefficients can be observed with the increment of the organic matter and of the clay percentage in soil, what indicates a greater retention capacity of the insecticide methylparathion in the Latossolo Roxo soil.

Results obtained for soils of Spain, possessing similar characteristics, showed close distribution coefficients $\left(\mathrm{K}_{\mathrm{d}}\right) .{ }^{18}$ For example, two Mollic Solonetz soils with $4.03 \%$ and $1.19 \%$ of organic matter presented $\mathrm{K}_{\mathrm{d}}$ of 17.3 and $9.16 \mathrm{~L} \mathrm{~kg}^{-1}$, respectively, which are very close to the values obtained for the Latossolo Vermelho Amarelo (17.8 $\left.\mathrm{L} \mathrm{kg}^{-1}\right)$ and Areia Quartzosa $\left(8.8 \mathrm{~L} \mathrm{~kg}^{-1}\right)$ soils, where the amounts of organic matter were $3.1 \%$ and $1.1 \%$, respectively. All these soils have the same mineralogy (mica and kaolinite) and therefore the organic matter governs the sorption process. However, the Latossolo Roxo soil presented higher $\mathrm{K}_{\mathrm{d}}\left(39.3 \mathrm{~L} \mathrm{~kg}^{-1}\right)$ for the relatively same amount of organic matter. This difference can be explained by the known presence of high amount of iron oxides in the Latossolo Roxo soil.

\section{Conclusions}

The electroanalytical procedure presented allows the accurate determination of methylparathion in soil samples. Application of the proposed methodology in soil sorption studies were conducted according to the IBAMA methodology providing sorption coefficients for three different soils. $\mathrm{K}_{\mathrm{F}}$ and $\mathrm{K}_{\mathrm{d}}$ coefficients were dependent on the soil parameters, mainly the content of organic matter and mineralogy.

Following the classification of IBAMA, which is based upon the values of $\mathrm{K}_{\mathrm{F}}$, the soil Areia Quartzosa is classified as of low sorption capacity and the soils Latossolo Vermelho Amarelo and Latossolo Roxo are classified as displaying medium sorption capacity.

\section{Acknowledgements}

The authors thank Conselho Nacional de Desenvolvimento Científico e Tecnológico (CNPq) for financial support (CT/Hidro 550188/2002-9 and 132144/2002-6).

\section{References}

1. Subbalakshmamma, M.; Reddy, S. J.; Electroanalysis 1994, 6, 521.

2. Compêndio de Defensivos Agrícolas, $5^{\text {th }}$ ed., Organização Andrei Editora Ltda: São Paulo, 1996.

3. Mulchandani, A.; Chen, W.; Mulchandani, P.; Wang, J.; Rogers, K. R.; Biosens. Bioelectron 2001, 16, 225.

4. Vaz, C. M. P.; Crestana, S.; Machado, S. A. S.; Mazo, L. H.; Massaropi, M. R. C.; Avaca, L. A.; Pesticidas, Rev. Tec. Cient. 1996, 6, 55.

5. Vaz, C. M. P.; Crestana, S.; Machado, S. A. S.; Mazo, L. H.; Avaca, L. A.; Intern. J. Environ. Anal. Chem. 1996, 62, 65.

6. Vaz, C. M. P.; Crestana, S.; Machado, S. A. S.; Mazo, L. H.; Avaca, L. A.; Electroanalysis. 1997, 9, 956.

7. Rupp, E. B.; Zuman, P.; Sestáková, I.; Horák, V. J.; Agric. Food Chem. 1992, 40, 2016.

8. Smyth, M. R.; Osteryoung, J. G.; Anal. Chim. Acta 1978, 96, 335.

9. Mandal, A. K.; Adhikari, M.; J. Indian Chem. Soc. 1997, 74, 114.

10. Manzanilla-Cano, J. A.; Reyes-Salas, E. O.; Barceló-Quintal, M. H.; Intern. J. Environ. Anal. Chem. 1999, 75, 387.

11 Zen, J-M.; Jou, J-J.; Kumar, A. S.; Anal. Chim. Acta 1999, 396, 39.

12. Smyth, M. R.; Osteryoung, J. G.; Anal. Chim. Acta 1978, 96, 335.

13. Khan, M. S.; Pakistan J. Sci. Ind. Res. 1988, 31, 20.

14. Dores, E. F. G. D.; De-Lamonica-Freire, E. M.; Quim. Nova 2001, 24, 27.

15. Instituto Brasileiro de Meio Ambiente e dos Recursos Renováveis; Manual de Pesticidas para Avaliação da Ecotoxidade de Agentes Químicos, $2^{\text {nd }}$ ed., IBAMA: Brasília, 1990.

16. Calvet, R.; Environ. Health Perspectives 1989, 83, 145.

17. Weber, J. B.; Miller, C. T.; In Reactions and Movement of Organic Chemicals in Soil, Sawhney, B. L.; Brown, K., ed., SSSA: Madison (SSSA Special Publication, 22), 1991, 12, 305.

18. El M’Rabert, M.; Dahchour, A.; Massouri, M.; Sanchez-Martin, M.; J. Fresenius Environ. Bull. 2000, 9, 582.

Received: January 31, 2003

Published on the web: August 14, 2003

FAPESP helped in meeting the publication costs of this article. 